\title{
DPSIR-Two Decades of Trying to Develop a Unifying Framework for Marine Environmental Management?
}

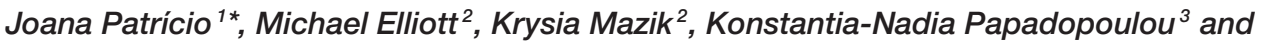 \\ Christopher J. Smith ${ }^{3}$
}

\footnotetext{
${ }^{1}$ European Commission, Joint Research Centre, Directorate for Sustainable Resources, D.2 Water and Marine Resources Unit, Ispra, Italy, ${ }^{2}$ Institute of Estuarine and Coastal Studies, University of Hull, Hull, UK, ${ }^{3}$ Hellenic Centre for Marine Research, Crete, Greece
}

\section{OPEN ACCESS}

Edited by:

Angel Borja,

AZTI, Spain

Reviewed by:

Angel Pérez-Ruzafa,

University of Murcia, Spain

Ana Isabel Lillebo,

University of Aveiro, Portugal

*Correspondence:

Joana Patrício

joanamateuspatricio@gmail.com

Specialty section:

This article was submitted to Marine Ecosystem Ecology,

a section of the journal

Frontiers in Marine Science

Received: 01 June 2016 Accepted: 01 September 2016 Published: 14 September 2016

Citation:

Patrício J, Elliott M, Mazik K Papadopoulou K-N and Smith CJ (2016) DPSIR-Two Decades of

Trying to Develop a Unifying Framework for Marine Environmental Management? Front. Mar. Sci. 3:177. doi: 10.3389/fmars.2016.00177
Determining and assessing the links between human pressures and state-changes in marine and coastal ecosystems remains a challenge. Although there are several conceptual frameworks for describing these links, the Drivers-Pressures-State change-Impact-Response (DPSIR) framework has been widely adopted. Two possible reasons for this are: either the framework fulfills a major role, resulting from convergent evolution, or the framework is used often merely because it is used often, albeit uncritically. This comprehensive review, with lessons learned after two decades of use, shows that the approach is needed and there has been a convergent evolution in approach for coastal and marine ecosystem management. There are now 25 derivative schemes and a widespread and increasing usage of the DPSIR-type conceptual framework as a means of structuring and analyzing information in management and decision-making across ecosystems. However, there is less use of DPSIR in fully marine ecosystems and even this was mainly restricted to European literature. Around half of the studies are explicitly conceptual, not illustrating a solid case study. Despite its popularity since the early 1990s among the scientific community and the recommendation of several international institutions (e.g., OECD, EU, EPA, EEA) for its application, the framework has notable weaknesses to be addressed. These primarily relate to the long standing variation in interpretation (mainly between natural and social scientists) of the different components (particularly P, S, and I) and to over-simplification of environmental problems such that cause-effect relationships cannot be adequately understood by treating the different DPSIR components as being mutually exclusive. More complex, nested, conceptual models and models with improved clarity are required to assess pressure-state change links in marine and coastal ecosystems. Our analysis shows that, because of its complexity, marine assessment and management constitutes a "wicked problem" and that there is an increasing need for a unifying approach, especially with the implementation of holistic regulations (e.g., European framework Directives). We emphasize the value of merging natural and social sciences and in showing similarities across human and natural environmental health. We show that previous approaches have adequately given conceptual and generic models but specificity and quantification is required.

Keywords: biodiversity, conceptual framework, drivers, pressures, state, impacts, response, environmental assessment 


\section{INTRODUCTION}

The highly-complex marine system has a large number of interrelated processes acting between its physical, chemical, and biological components. Many diverse human activities exert pressure on this complex environment and the cumulative environmental effects of these activities on the system varies according to the intensity, number and spatial and temporal scales of the associated pressures. There is an increasing need to demonstrate, quantify predict and communicate the effects of human activities on these interrelated components in space and time (Elliott, 2002). The study and management of marine systems therefore requires information on the links between these human activities and effects on structure, functioning and biodiversity, across different regional seas in a changing world. It also requires the need to merge approaches from natural and social sciences in structuring and solving the problems created by human activities in the seas (Gregory et al., 2013).

Conceptual models are needed to collate, visualize, understand and explain the issues and problems relating to actual or predicted situations and how they might be solved. These models can be regarded as organizational diagrams, which bring together and summarize information in a standard, logical and hierarchical way. Since the early 1990s, Pressure-State-Response (PSR) frameworks have been central to conceptualizing marine ecosystem risk analysis and risk management issues and then translating those for stakeholders, environmental managers and researchers. In this context, the pressures cause the changes to the system, the state changes are the unwanted changes and the responses are what society does to remove, minimize, or accommodate the changes. Hence, it is axiomatic that society has to be concerned about the risks to the natural and human system posed by those pressures (thus needing risk assessment) and then it is required to act to minimize or compensate those risks (as risk management) (Elliott et al., 2014).

It is apparent that one of the key current conceptual frameworks in widespread use, the Drivers-Pressures-State change-Impact-Response (DPSIR) framework (see Figure 1Aoriginal concept and definitions from EC, 1999), has developed since the 1990s as the basis for most conceptual approaches addressing pressure-state change links. It is policy-oriented and provides a framework for categorizing a problem domain, along the cause-effect chain. The DPSIR framework was developed from the PSR framework initially proposed by Rapport and Friend (1979), and adapted and largely promoted by the OECD (Organization for Economic Cooperation and Development) for its environmental reporting (OECD, 1993). Several international organizations, such as US Environmental Protection Agency (EPA, 1994), UNEP (1994) and the EU have also adopted the framework, the latter noting that this was the most appropriate way to structure environmental information (EC, 1999). Within the EU, Eurostat focuses on Response (the societal mechanisms effecting ecosystem management, in particular, expenditure on environmental protection), Driving forces (environmentally relevant sectoral trends, for example, societal need for and food) and Pressure (e.g., resource exploitation trends). Indicators of State and Impact are the domain of the European Environment
Agency (EC, 1999) which is required to communicate the state of the environment for policy-makers. DPSIR has thus been used with increasing frequency for problem solving both by natural and social scientists and they have further refined/defined and applied DPSIR and its derivatives in an on-going process tailored to many different applications.

Gari et al. (2015) recently reviewed 79 published and gray literature sources involving eight DPSIR derivatives for coastal social-ecological systems. More recently, Lewison et al. (2016) reviewed many papers covering 24 relevant DPSIR coastal zone articles. Both publications point out limitations and in particular differences in the terminology or definitions used by different authors. Important differences in definitions particularly concerning States and Impacts, had led to the "modified DPSIR" (mDPSIR) of the ELME EU FP6 project. Within mDPSIR the Impact category was restricted to impacts on human systems thus leading in turn to the definition of the DPSWR framework in the KNOWSEAS FP7 project, where Cooper (2013) replaced Impact with Welfare. However, it has been suggested that it is the "impact on human welfare" rather than "welfare" per se that is important hence leading to the most recent DAPSI $(\mathrm{W}) \mathrm{R}(\mathrm{M})$ derivative (Wolanski and Elliott, 2015; Scharin et al., 2016) (Figure 1B). In another modification, used by social scientists, DPSIR has been related to Goods and Services through EBMDPSER where Ecosystem Based Management (EBM) is directly related to Driver-Pressure-State-Ecosystem Service-Response (Kelble et al., 2013) or the Ecosystem Services and Societal Benefits (ES\&SB) linked-DPSIR approach (Atkins et al., 2011). A further development of DPSIR in the area of human health has been the DPSEEA framework comprising Driving forces-Pressures-State-Exposure-Effect-Action (and sometimes DPSEEAC, where "C" relates to Context), a framework used primarily in risk assessments for contaminants and developed by the World Health Organization (von Schirnding, 2002). Given that such a framework requires indicators to determine whether management actions are effective, successful and sustainable (Elliott, 2011), a further development was in creating indicators such as those of child environmental health using the MEME framework (many-exposures many-effects); this therefore progressed from the linear and pollution-based view of DPSEEA (and other) frameworks (Briggs, 2003).

Given the above history and confusion, as part of the EU funded DEVOTES project (see http://www.devotesproject.eu), we have comprehensively reviewed marine/coastal environmental investigations concerned with the DPSIR framework and its derivatives. We have furthermore assessed its applications, habitats addressed, geographical use, problems and developments, and the general advantages and disadvantages of using the framework to address marine issues. Our aim was to establish the extent to which DPSIR as an overarching framework has been applied to marine and coastal ecosystems and to identify factors which either facilitate or hinder its application. In this way, we focus on the ability and adequacy of the DPSIR framework to analyze and explain the relationships between human uses of the seas and the resulting problems, their management and the communication of these to interested 


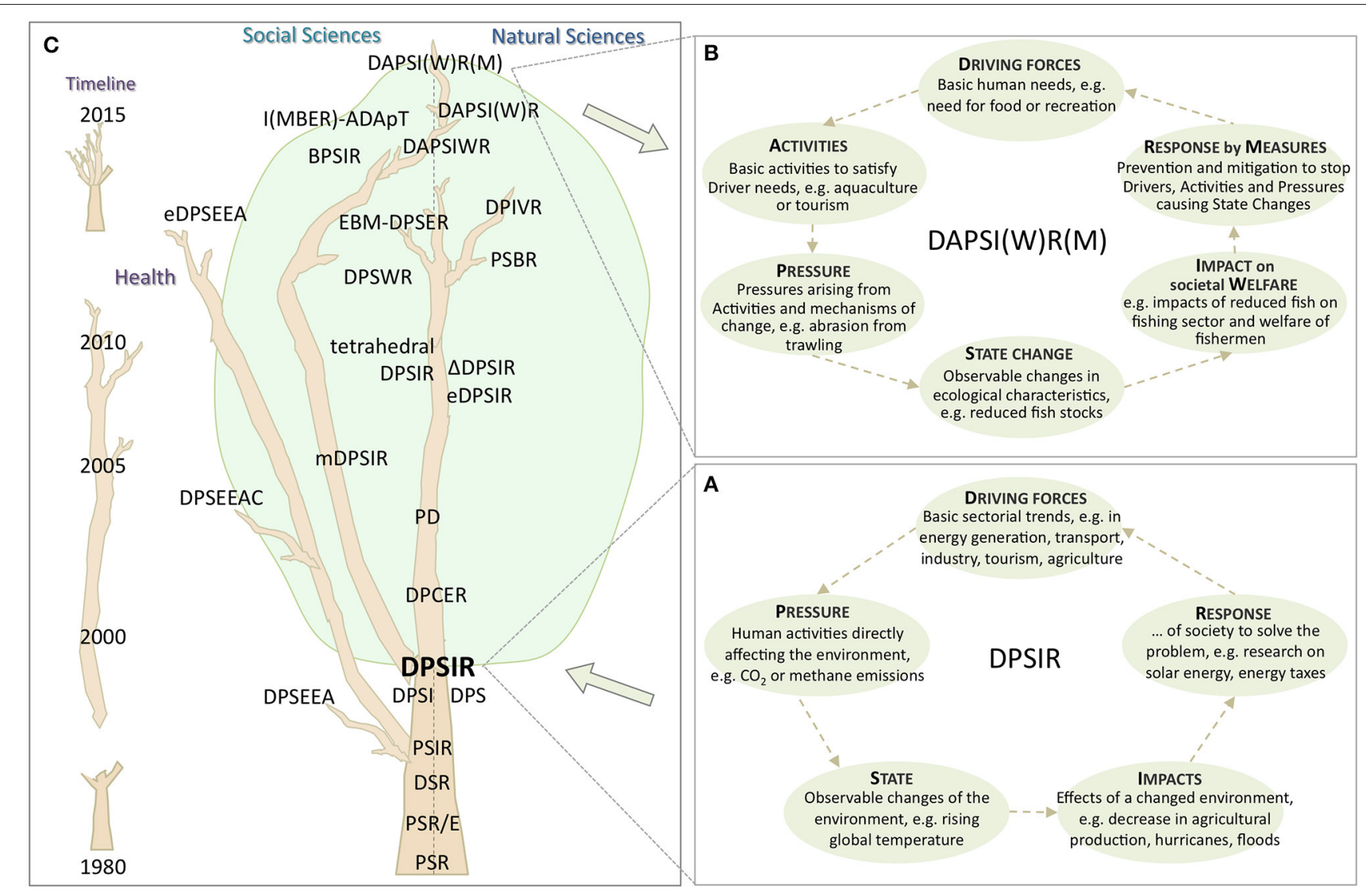

FIGURE 1 | DPSIR and derivatives development. (A) DPSIR first elaboration, redrawn from the original EU framework (EC, 1999), (B) DAPSI(W)R(M), top of the tree evolution of DPSIR (as defined in Scharin et al., 2016), (C) timeline and development/relationship of DPSIR and derivatives.

stakeholders. To our knowledge, this is the first study that summarizes the use of DPSIR in marine ecosystems.

\section{MATERIALS AND METHODS}

This comprehensive review of the available literature concerned with the DPSIR framework, its "derivatives" and other related frameworks. We used the following search keywords both singly and in combination: DPSIR, PSR, Drivers + Pressures + State + Impacts + Responses, State change, conceptual framework, Marine and Coastal. We conducted primary searches using Web of Science, ScienceDirect, Scopus and Google Scholar and then checked the reference lists of the previous review papers. We only considered publications published in English. We furthermore compiled projects starting with an initial list of European projects where DPSIR was known to be used as a conceptual framework and then we expanded the search using the same keywords used for publications plus the word "project." Our keywordbased screening was narrowed according to the text in the abstracts. We retained documents when the abstract explicitly mentioned the DPSIR framework or any derivative and was linked with coastal or marine ecosystems. Although this review focused primarily on research projects and publications dealing with these ecosystems, the scope broadened to include both projects and publications that present or discuss the framework, regardless of its application to specific case studies and studies that address biodiversity (sensu lato) under the scope of DPSIR.

The 152 studies retained for the review included research papers, review papers, essays, short communications, viewpoint papers, seminar papers, discussion papers, journal editorials, policy briefs, conference long abstracts, monographs, technical reports, manuals, synthesis or final project reports and book chapters (Figure 2A). The studies were collated and, after detailed reading, each reference was categorized by "Study site," "Habitat," "Region," "Framework/Model type," "Issue/problem addressed by the study," "Implementation level" and "Type of publication." Appendix 1 in Supplementary Material presents the final list of references and their classification according to the previous categories.

The analysis also considered research projects from 1999 onwards and showed that at least 27-research projects focusing on coastal and marine habitats have used (or are using) the DPSIR framework and/or derivatives as part of their conceptual development phases. Appendix 2 in Supplementary Material shows the final list of projects that were considered, categorized by "Acronym," “Title," "Duration," "Funding institution," "Region," "General objective" of the project, "Framework" used, "Keywords," "Website" and some examples of "Output 


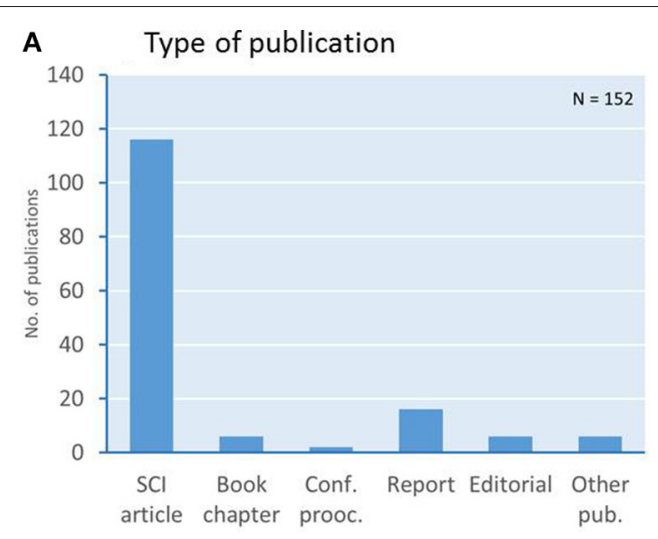

C Implementation level

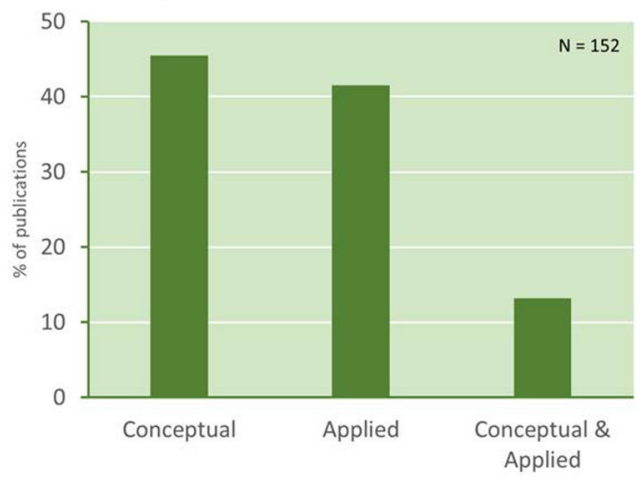

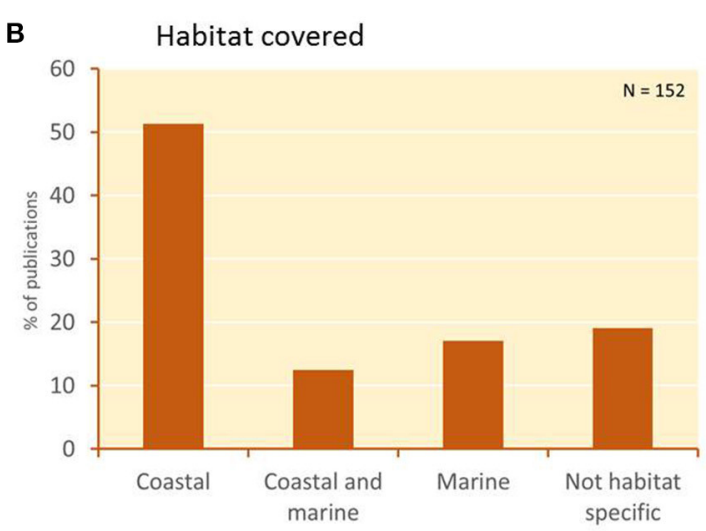

D

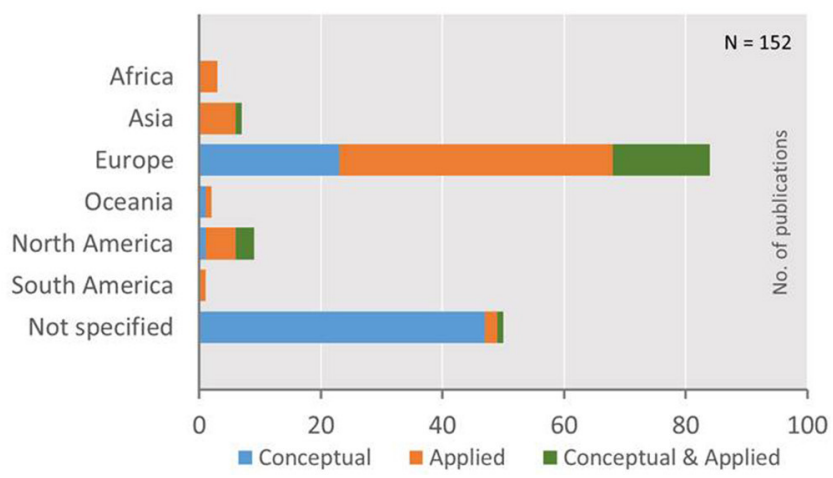

FIGURE 2 | (A) Types of publication; (B) Habitats covered; (C) Implementation level; and (D) geographical coverage.

references." A further column gives complementary details for the projects where available.

Box 1 shows the 25 frameworks found in the review and the general components of each conceptual model.

\section{RESULTS}

\section{Published Investigations}

Despite the increasing popularity of the DPSIR framework and derivative models among the scientific community since the early 1990s, and the recommendations of OECD (1993), EPA (1994), EEA (1999), and EC (1999) for its application, few studies have focused on the marine habitat (Figure 2B). From our comprehensive review, only 26 studies exclusively cover this habitat and from these, only eight illustrate concrete case studies [German Exclusive Economic Zone (Fock et al., 2011); German waters of the North Sea (Gimpel et al., 2013); Baltic Sea, Black Sea, Mediterranean Sea, and North East Atlantic Ocean (Langmead et al., 2007, 2009); Baltic Sea (Andrulewicz, 2005); North and Baltic Sea (Sundblad et al., 2014); Northwestern part of the North Sea (Tett et al., 2013) and Florida Keys and Dry Tortugas (Kelble et al., 2013)]. The remaining 18 studies are either explicitly conceptual or illustrate the framework with generic situations/issues. For example, Elliott (2002) examined offshore wind power and Ojeda-Martínez et al. (2009) studied the management of marine protected areas.

In addition to studies exclusively focusing on marine habitats, 19 others focused simultaneously on marine and coastal habitats (13 of them applied). These cover the Mediterranean region (Casazza et al., 2002), Portuguese marine and coastal waters (Henriques et al., 2008), German North Sea (Lange et al., 2010), West coast of Schleswig-Holstein (Licht-Eggert, 2007), Baltic Sea (Lundberg, 2005; Ness et al., 2010; Lowe et al., 2014), Dutch Wadden Sea region (Vugteveen et al., 2014), UK waters (Rogers and Greenaway, 2005; Atkins et al., 2011), the North East Atlantic (Turner et al., 2010) and the Black Sea (Hills et al., 2013).

Approximately half of the references focus explicitly on coastal habitats (e.g., estuaries, coastal lagoons, entire basins) and half of these are solid case studies where, to a lesser or greater extent, the DPSIR framework or derivatives were applied (for examples, see Box 2). The remaining references $(N=29)$ are not habitat-specific (Figure 2B). Approximately 45\% of the studies are conceptual (i.e., defining or reviewing the frameworks, using DPSIR and derivatives as reporting outline or as a framework for selecting environmental indicators, assessing biodiversity loss, etc.) (Figure 2C).

It is also of note that most publications refer to the use of DPSIR as a framework for specific issues (Box 2), for gaining greater understanding, as a research tool, for capturing and 


\section{BOX 1 | FRAMEWORKS FOUND IN THE REVIEW AND THEIR BASIC COMPONENTS.}

- BPSIR: Behavior - Pressure - State - Impact - Response

- DAPSI(W)R: Drivers - Activities - Pressures - State (change) - Impacts on human Welfare - Response

- DAPSIWR: Drivers - Activities - Pressures - State (change) - Impacts on environment - Impacts on welfare - Response

- DAPSI(M)R(M): Drivers - Activities - Pressures - State change - Impacts (on human Welfare) Response (using Measures)

- DPCER: Driver - Pressure - Chemical state - Ecological state - Response

- DPS: Driver - Pressure - State

- DPSEA: Driver - Pressure - State - Effect - Action

- DPSEEA: Driver - Pressure - State - Exposure - Effect - Action

- DPSEEAC: Driver - Pressure - State - Exposure - Effect - Action - Context

- DPSI: Driver - Pressure - State - Impact

- DPSIR: Driver - Pressure - State - Impact - Response

- DPIVR: Drivers - Pressures - Impacts - Vulnerability - Response

- $\triangle \mathrm{DPSIR}$ - Differential Drivers - Pressure - State - Impact - Response

- DPSWR: Driver - Pressure - State (change) - Welfare - Response

- DSR: Drivers - State - Response

- EBM-DPSER (or DPSER-EBM): Ecosystem Based Management/Driver - Pressure - State - Ecosystem service - Response

- eDPSEEA: ecosystems-enriched Driver - Pressure - State - Exposure - Effect - Actions

- eDPSIR: enhanced Driver - Pressure - State - Impact - Response

- I(MBER)-ADApT: Assessment based on Description, Response and Appraisal for a Typology

- mDPSIR: Driver - Pressure - State - Impact - Response

- PD: Pressures - Drivers

- PSBR: Pressure - State - Benefits - Response

- PSIR: Pressure - State - Impact - Response

- PSR/E: Pressure - State - Response - Effects

- Tetrahedral DPSIR: Driver - Pressure - State - Impact - Response (adapted)

\section{BOX 2 | KEY AND RECENT PUBLICATIONS IN WHICH DPSIR AND DERIVATIVES HAVE BEEN USED. \\ Uses of DPSIR framework $\quad$ Indicative references}

Development and selection of indicators

Bowen and Ryley, 2003; EPA, 2008; Espinoza-Tenorio et al., 2010; Bell, 2012; Perry and Masson, 2013; Pettersson, 2015

Assessment of eutrophication

Bricker et al., 2003; Cave et al., 2003; Newton et al., 2003; Karageorgis et al., 2005; Lundberg, 2005; Nunneri and Hofmann, 2005; Pirrone et al., 2005; Rovira and Pardo, 2006; Trombino et al., 2007; Zaldívar et al., 2008; Gari, 2010; Garmendia et al., 2012

Assessment of the impact and vulnerabilities of climate change

Holman et al., 2005; Hills et al., 2013; Hossain et al., 2015

Fisheries and/or aquaculture management

Rudd, 2004; Mangi et al., 2007; Marinov et al., 2007; Viaroli et al., 2007; Henriques et al., 2008; Hoff et al., 2008 in Turner et al., 2010; Knudsen et al., 2010; Ou and Liu, 2010; Nobre et al., 2011; Cranford et al., 2012; Martins et al., 2012

Integrated coastal management

Turner et al., 1998b, 2010; EEA, 1999; Licht-Eggert, 2007; Mateus and Campuzano, 2008; Schernewski, 2008; Vacchi et al., 2014; Vugteveen et al., 2014; Dolbeth et al., 2016

Management of marine aggregates Atkins et al., 2011; Cooper, 2013

Assessment of seagrass decline Azevedo et al., 2013

Management of water resources Giupponi, 2002, 2007; Mysiak et al., 2005; Yee et al., 2015

Assessment of wind farm consequences Elliott, 2002; Lange et al., 2010

Ecosystem health assessment Tett et al., 2013; Wang et al., 2013

Framing monitoring activities Pastres and Solidoro, 2012

Synthesis of information related with ecosystem goods and services

communicating complex relationships, as a tool for stakeholder engagement, as the subject of reviews and as the subject for further tool/methodology development linked to policy making and decision support systems. For example, Cormier et al. (2013), using Canadian and European approaches, emphasized DPSIR as a Risk Assessment and Risk Management framework and 
recommend that ICES (International Council for the Exploration of the Sea) uses this as their underlying rationale for assessing single and multiple pressures.

This review shows clearly that the DPSIR framework and its extensions have mainly been used in a European context (Figure 2D). If we consider only those studies that specify a geographical location $(N=100)$, only $20 \%$ of the studies were performed in other regions (e.g., EPA, 1994, 2008; Bricker et al., 2003; Espinoza-Tenorio et al., 2010; Kelble et al., 2013; Perry and Masson, 2013; Cook et al., 2014; Fletcher et al., 2014; Yee et al., 2015 in North America; Bidone and Lacerda, 2004 in South America; Turner et al., 1998a; Lin et al., 2007; Ou and Liu, 2010; Nobre et al., 2011; Wang et al., 2013; Zhang and Zue, 2013; Hossain et al., 2015 in Asia; Walmsley, 2002; Mangi et al., 2007; Scheren et al., 2004 in Africa; Cox et al., 2004; Butler et al., 2014 in Oceania).

\section{Research Projects}

Since 1999, at least 27-research projects focusing on coastal and marine habitats have used (or are using) the DPSIR framework and/or derivatives as part of their conceptual development phases (Appendix 2 in Supplementary Material). Three of these projects had a scope beyond coastal and marine ecosystems, aiming to tackle large-scale environmental risks to biodiversity (e.g., ALARM), to contribute to the progress of Sustainability Science (e.g., THRESHOLDS) and to identify and assess integrated EU climate change policy (e.g., RESPONSES). They have been included in this review as their findings can extend to coastal and marine habitats. One of these projects (ResponSEAble, see Appendix 2 in Supplementary Material for more details) specifically addresses the human-ocean relationship and the need to encourage Europeans to treat oceans with greater respect and understanding (see Box 3).

Hence the DPSIR is a framework that several European projects have applied and/or developed but is less commonly the case in non-EU areas. From the many projects that used the framework or derivatives, only one was non-European funded. The USA National Oceanic and Atmospheric Administration Centre for Sponsored Coastal Ocean Research supported the MARES project that developed the EBM-DPSER framework (see Kelble et al., 2013; Nuttle and Fletcher, 2013).

In addition to the scientific context, the role played by the DPSIR framework and/or derivatives also varied markedly from project to project: ELME, KNOWSEAS, ODEMM, DEVOTES, and VECTORS have used the DPSIR framework extensively and some of these projects have developed and further modified the framework (e.g., ELME-mDPSIR and KNOWSEAS-DPSWR). However, this review encountered some difficulties mainly in relation to accessing information (see ${ }^{*}$ in Box 3 ). In other projects, it has been difficult to find specific content even with a careful and thorough examination of websites, lists of deliverables and publications. The lack of easy openaccess acts as a constraint to apply and explore further the knowledge gained by the application of the conceptual frameworks.

\section{DISCUSSION}

The DPSIR framework, as used widely in the literature, aims to act as a tool linking applied science and management of human uses (and abuses) of the seas. Because of this, and as shown here, it is necessary to define the framework and its terms and to show how the framework has been used, to indicate its advantages and benefits, as well as its disadvantages and anomalies. Most importantly there is the need to show whether it fulfills a role and whether it needs modifying and, if so, how it should be modified for future applications in an increasingly complex system of marine uses, users, threats, problems, and management repercussions. In particular, if successful, the DPSIR framework presents a simplified visualization and means of interrogating and managing complex cause-effect relationships between human activities, the environment, and society. It can therefore be used to communicate between disciplines (Tscherning et al., 2012), addressing the different aspects of environmental management (research, monitoring, mitigation, policy, and society) and between scientists, policy makers, and the public (Niemeijer and de Groot, 2008; Tscherning et al., 2012).

\section{DPSIR-Advantages and Benefits as a Holistic Framework DPSIR-A Wide-Ranging Tool Applicable to All Types of Environmental Problems}

Through identifying the progressive chain of events leading to state change, impact, and response, the DPSIR framework and derivatives can potentially be applied to all types of environmental problems. For example, Fock et al. (2011) used PSR to link marine fisheries to environmental objectives concerning seafloor integrity in the German EEZ (Economic Exclusive Zone). Langmead et al. (2007) used mDPSIR to organize information relating habitat change, eutrophication, chemical pollution, and fishing in several European seas. Hills et al. (2013) used DPIVR to assess the impact of, and the vulnerability of marine and coastal ecosystems to, climate change. Lange et al. (2010) used DPSIR to analyse coastal and marine ecosystem changes related with offshore wind farming. Additionally, the framework and its derivatives, have been often used to select and develop indicators for environmental analysis (e.g., Casazza et al., 2002; Andrulewicz, 2005; Rogers and Greenaway, 2005) and inform management decisions (Kelble et al., 2013).

\section{DPSIR-A Tool for Risk Assessment and Risk Management}

While the DPSIR framework has been used for certain types of problems in the marine environment, the most important aspect is in tackling a set of hazards which, if they adversely affect human assets, economy and safety, become risks to society (Elliott et al., 2014). The hazards may be from natural sources, such as erosion patterns, tsunamis, or isostatic rebound due to geological phenomena. More importantly, from a societal view, they may be anthropogenic such as the over-extraction of material from the sea, the input of chemicals or the building of structures such as windfarms. Human actions may exacerbate the hazards and 


\begin{tabular}{|c|c|}
\hline Areas in which the framework is used & Indicative EU Project (* website no longer active) \\
\hline To improve Integrated Coastal Zone Management and planning maritime safety & e.g., BLAST \\
\hline integration of climate change into development planning & e.g., CLIMBIZ, RESPONSES, LAGOONS \\
\hline To provide a roadmap to sustainable integration of aquaculture and fisheries & e.g., COEXIST \\
\hline $\begin{array}{l}\text { application of an ecosystem based marine management, the Ecosystem } \\
\text { Approach to management or to fisheries }\end{array}$ & e.g., ODEMM, KNOWSEAS, CREAM \\
\hline $\begin{array}{l}\text { To integrate the marine and human system and assess human activity and its } \\
\text { social, economic and cultural aspects }\end{array}$ & $\begin{array}{l}\text { e.g., ELME*, KNOWSEAS, VECTORS, ODEMM, BS-HOTSPOTS, } \\
\text { PERSEUS, DEVOTES }\end{array}$ \\
\hline $\begin{array}{l}\text { To support scientifically the implementation of several European directives and } \\
\text { legislation }\end{array}$ & $\begin{array}{l}\text { e.g., ODEMM, LAGOONS, MULINO, SPICOSA, KNOWSEAS, PERSEUS, } \\
\text { DEVOTES }\end{array}$ \\
\hline $\begin{array}{l}\text { To improve the knowledge of how environmental and man-made factors are } \\
\text { impacting the marine ecosystems and are affecting the range of ecosystem } \\
\text { goods and services provided }\end{array}$ & e.g., VECTORS, ODEMM, DEVOTES, SESAME*, LAGOONS \\
\hline To produce integrated management tools & e.g., MESMA, ODEMM, DITTY*, MULINO, LAGOONS, DEVOTES \\
\hline To look at spatial management and conflicts/synergies/trade offs & e.g., MESMA, COEXIST, ODEMM \\
\hline $\begin{array}{l}\text { To look at sectoral growth scenarios, sustainability, blue growth and the } \\
\text { challenge of good environmental status }\end{array}$ & e.g., MEDTRENDS \\
\hline To produce threat, risk and pressure assessment & e.g., ODEMM, DEVOTES \\
\hline $\begin{array}{l}\text { To produce new biodiversity indicators and Environmental Status assessment } \\
\text { tools }\end{array}$ & e.g., DEVOTES \\
\hline $\begin{array}{l}\text { To produce engaging and informative story lines and tools about the oceans to } \\
\text { raise interest and awareness among Europeans }\end{array}$ & e.g., ResponSEAble \\
\hline
\end{tabular}

lead to greater risks such as the removal of a protective saltmarsh or seagrass bed which otherwise could absorb energy and reduce erosion and the consequences of sea-level rise (Elliott et al., 2016). As such those human-induced hazards and risks emanate from activities and thus lead to the pressures as mechanisms resulting in adverse effects unless mitigated; consequently management responses as measures are required to address, mitigate or reduce those hazards and risks.

Each of those risks requires assessment, both cumulatively and in-combination thus requiring a rigorous framework that can accommodate multiple risks. Cumulative threats and pressures emanate from within one activity whereas in-combination threats and pressures arise from multiple activities occurring concurrently in an area. Therefore, once the risks are identified, by determining the source or cause of the threat and its consequences for the marine system, there needs to be a rigorous risk management framework (Cormier et al., 2013) which has to encompass a suite of measures by covering social, governance, economic, and technological aspects (Barnard and Elliott, 2015). This risk assessment and risk management framework thus especially encompasses the DPSIR approach in which the source and causes of risk are the Drivers and Pressures, the consequences are the State Change and Impacts and the risk is managed through the Responses (see Cormier et al., 2013).

\section{DPSIR-A Stakeholder-Inclusive and Communication Tool for Implementing the Ecosystem Approach}

DPSIR use has been adopted by and demonstrated to various actors, including research, academia, central and regional policy and decision makers, environmental NGOs, and the wider public. As an example, the EBM-DPSER model for the Florida Keys and Dry Tortugas is the agreed outcome of the joint efforts of over 60 scientists, agency resource managers, and environmental non-governmental organizations (Kelble et al., 2013). Various central administration bodies in Europe have used or are using the framework including, for example, the EEA, UNEP, and the Black Sea Commission (e.g., CLIMBITZ and BS-HOTSPOTS projects). UNEP used the framework as the base for organizing its State of the Environment assessment report (UNEP/MAP., 2012) by including an overview of major drivers in the Mediterranean, an analysis of the pressures, state and known impacts associated with each of the issues addressed by the Ecosystem Approach Ecological Objectives as well as major policy responses. Environmental NGOs have used the framework to present the main issues and to focus their needfor-change message to both the public and policy makers (e.g., WWF, MEDTRENDS project). Despite this, the level of detail depicted in these mostly conceptual applications of the DPSIR framework varies greatly. Most of the publications and projects included in this review do not go beyond the conceptual level 
although some of the conceptual models do include more details and/or more levels (e.g., Atkins et al., 2011). While O'Higgins et al. (2014) and Scharin et al. (2016) use the framework as a tool to analyse the relationship between human activities and their Impacts or to capture the information needed for marine management, Pettersson (2015) presents a case around eDPSIR and the Port of Gothenburg that includes development of indicators for factors influencing biodiversity and for the assessment of biodiversity itself. Pastres and Solidoro (2012), for the Venice lagoon, emphasize the importance of adopting a DPSIR approach to monitoring strongly supported by modeling tools and mathematical models as these can provide quantitative links between Pressures and State/Impacts. Furthermore, Cook et al. (2014) use detailed conceptual models (EBM-DPSER) together with expert opinion and matrix analyses to explore the direct and indirect relative impact of 12 ecosystem pressures on 11 ecosystem states and 11 ecosystem services.

\section{DPSIR-Disadvantages and Anomalies DPSIR-Restricted Coverage and Application}

It is emphasized here that there is a widespread and increasing usage of DPSIR-type conceptual framework models in management and issue-resolving. Although many papers are conceptual, there are more case studies over time either used to describe an issue, thereby communicating a problem with an emphasis on the P-S link, where the natural scientists can apply a high degree of detail, or give the framework entirety across the whole cycle, solving problems through management with more involvement of social scientists, but less detail on the P-S links. In a more restricted study, Lewison et al. (2016) noted that only eight of the 24 DPSIR articles that they reviewed actively engaged decision-makers or citizens in their research, thereby completing a full cycle or involving all stakeholders. Bell (2012) emphasized that the challenge for DPSIR is to be both a precise Problem Structuring Method and of wide use to stakeholders.

It is of note that the analysis here clearly shows that the use of DPSIR is primarily European-based, also noted in the Lewison et al. (2016) review, with surprisingly sparse use elsewhere such as in the USA. This should not necessarily be regarded as a less-holistic or integrated approach to environmental issues, although it may be the result of the European framework directives guiding sustainability becoming increasingly complex, inclusive and integrated with respect to ecosystems, humans, and their activities (Boyes and Elliott, 2014). However, driving the European use is not just the institutional organizations of the EU, but also growth through parallel and sequential funding of European projects supporting those EU framework directives, that have used DPSIR as a central pillar in environmental problem-framing. As indicated above, it has been recognized as a valuable problem structuring method, both within scientific circles as well as its adoption by international organizations. It is perhaps less surprising that there is less use in fully marine systems than in coastal systems, where there are greater populations and environmental problems. In our comprehensive review, only 26 studies covered exclusively marine habitats and from these only eight illustrate concrete case studies. It is expected that in future more studies will focus on fully marine ecosystem due to the further implementation of the European Marine Strategy Framework Directive (2008/56/EC) and the European Marine Spatial Planning Directive (2014/89/EU).

\section{DPSIR-Non-standard Use of Terms}

The wide variety of derivatives is shown in their evolution over time in Figure 1C. Most of the frameworks derive directly from DPSIR after 1999, although the DPSEEA-eDPSEEA branch used primarily in health/medicine appeared to diverge earlier. There is some differentiation in use between social sciences and natural sciences, although theoretically DPSIR and close derivatives should cover both types of science. However, more emphasis may be on one or the other depending on the use, where natural scientists may have stronger emphasis on the pressure/state side and the social scientist may have greater emphasis on the impact/response/drivers side. This emphasizes the singular essence of using the DPSIR framework and derivatives in its holistic treatment bridging natural and socio-economic systems and in being a common framework applicable to human and environmental health.

The large number of derivatives indicates that use is wideopen to interpretation and our experience has shown that even specifically within DPSIR there is a high degree of variation in how the major components are interpreted or defined. It thus becomes necessary to define how it is used in every study otherwise there is great confusion in whether a component is ascribed to driver/pressure, pressure/state, or state/impact (Wolanski and Elliott, 2015; Scharin et al., 2016). Under the DPSIR framework (EEA, 1999), there has been longstanding variation in the interpretation and use of various components Drivers-Pressures-State change-Impact-Response, in particular in relation to the P, S, and I components. For example, the term "pressure" is commonly used interchangeably with "activity" or Driving force (Robinson et al., 2008). Similarly, state change and impact are both commonly used in the context of impacts on the environment (Eastwood et al., 2007) whereas impact also commonly refers to the impact on society brought about by a state change to the environment (Atkins et al., 2011). This issue is highlighted by Martins et al. (2012) who also noted variation in the use of indicators between studies (in a fisheries context) as a direct result of this misinterpretation. Whilst there are multiple matrices of the links between sectors, activities and pressures, this has not been carried through to the links between pressures and state changes, state changes and impacts and pressures and impacts, probably due to the large number and complexity of these interactions. Most importantly, the links have not been quantified but remain mostly at the conceptual level.

The recent developments within and between recent EU funded projects (see above), often through their common membership by participants, has helped to standardize definitions and component lists and has given a more rigid structure in starting from concepts and moving to assessments, even though they may have used different definitions.

\section{DPSIR-Oversimplifies the Problems}

It is emphasized that the concept of DPSIR is well-illustrated to be sound in that it presents a logical, stepwise chain of 
cause-effect-control events that describe the progression from identification of a problem to its management. However, its application requires a deeper understanding of the relationships between the different DPSIR components (Bell, 2012) before the concept can be effectively applied and its limitations need to be acknowledged. For example, P-S-I components are not mutually exclusive, despite being commonly treated as such. In particular, the $\mathrm{P}$ and $\mathrm{S}$ components are strongly linked in that Pressure, as the mechanism of change, causes a number of physical state changes that ultimately lead to biological change (hence the variation in the interpretation of that described by the P, S, and I components), or it can cause immediate biological change. The timescale over which this change occurs is variable and, in dose-response terms, can be chronic (subtle over long time periods) or acute (immediate). However, a discrete classification of pressures and state changes does not acknowledge this (Niemeijer and de Groot, 2008; Svarstad et al., 2008) and therefore overlooks an important part of the process leading to state change. Whilst activities are linked to both the D and P components, DPSIR in its current form does not categorically address activities or follow the pathway through pressure, state change, and impact, thus not adequately illustrating clear cause-effect relationships (Carr et al., 2007), which makes it difficult to pinpoint management actions. This problem has been overcome by the DAPSI(W)R(M) model (Wolanski and Elliott, 2015; Scharin et al., 2016), at the top of the "evolutionary tree" in Figure 1C, where these relationships are inherently contained with a good balance between natural and social aspects.

The DPSIR approach has to reflect the increasing knowledge of the complexity in the system. It is widely acknowledged that multiple activities occur simultaneously and create incombination effects, that a single activity can give rise to multiple pressures (termed cumulative effects), that a pressure may not necessarily lead to a state change or impact, that a pressure associated with one activity may act differently to the same pressure associated with another activity and that the severity and the potential for state change may differ (Smith et al., 2016). Hence, it will be regarded as being oversimplified if DPSIR focuses on one-to-one relationships, disregarding the complex interactions between multiple pressures, activities, the environment, and society (Niemeijer and de Groot, 2008; Svarstad et al., 2008; Atkins et al., 2011; Tscherning et al., 2012). This can prevent early detection of state changes and impacts and therefore prevent timely, targeted management. Bell (2012) argued that targeted research was necessary to improve understanding of the $S$ and I components of DPSIR (i.e., the state of the environment and its links to social and cultural drivers and impacts on society).

\section{DPSIR-Solutions and Recommendations for the Way Ahead}

The existing models appear to be adequate for depicting the relationships between drivers/pressures and the habitat/biological component that might be affected (or have its state changed) but may be inadequate in addressing state change, what it is or how it arises. The science behind assessments is advancing as new knowledge becomes available, but it still has to deal with ecosystems that are complex, and where pressure-effect relationships on ecosystem components and interrelationships between these components are not fully understood at the quantitative level. This complexity is further highlighted by the $4000+$ potential regional seas sector-pressurecomponent "impact chains" identified from the ODEMM project with state change components only identified at the very highest level (Knights et al., 2015). Consequently, whilst DPSIR provides a strong and well-accepted concept, there is room for much more development in refining the concept, methodologies and applications.

\section{Clarity of Terms in the DPSIR Framework}

It has recently been concluded that the DPSIR approach and its terms have several anomalies and flaws which require it to be revised (Wolanski and Elliott, 2015; Burdon et al., 2015; Scharin et al., 2016). The main discussion is given elsewhere (see for example, Wolanski and Elliott, 2015; Scharin et al., 2016) but in brief, this contends that the terms require more accurate definition. Furthermore, the DPSIR framework does not categorically refer to the human activities which give rise to pressures. The most recent proposal to optimize the DPSIR framework for environmental management (DAPSI(W)R(M)) (pronounced "dapsiworm"), gives a more accurate and complete indication of the DPSIR framework (Wolanski and Elliott, 2015; Scharin et al., 2016, defined in Figure 1B). The original components of DPSIR, and their definitions, are retained but clarified by the inclusion of activities within the framework (Figure 3). The term Driver thus needs to refer to the basic human needs such as food, shelter, security, and goods. In order to obtain these, society carries out Activities (fishing, aggregate extraction, infrastructure building) which in turn create Pressures which are defined as the mechanisms whereby an Activity has an effect, either positive or negative. These effects, when on the natural system (the physico-chemical and ecological system) then need to be referred to as State Changes to separate them from State, a description of the characteristics at one time. These State changes thus encompass alterations to the substratum, the water column and their constituent biota.

Once these effects occur on the natural system then society is concerned that there will be a resulting change on human welfare and on the ecosystem services which ultimately produce societal benefits (Turner and Schaafsma, 2015). Hence, this Impact is on the human Welfare. Those Impacts on human Welfare and State Changes on the natural system then need to be addressed using Responses. As the EU Directives refer to these responses as Measures then we can use the final term as Responses (using Measures). Those measures then include economic and legal instruments, technological devices, remediation agents, and societal desires (Barnard and Elliott, 2015).

\section{Expansion of DPSIR-Coping with Complexity}

Although as indicated above, DPSIR cannot remain merely a very good concept dealing with a single driver/activity/pressure, 


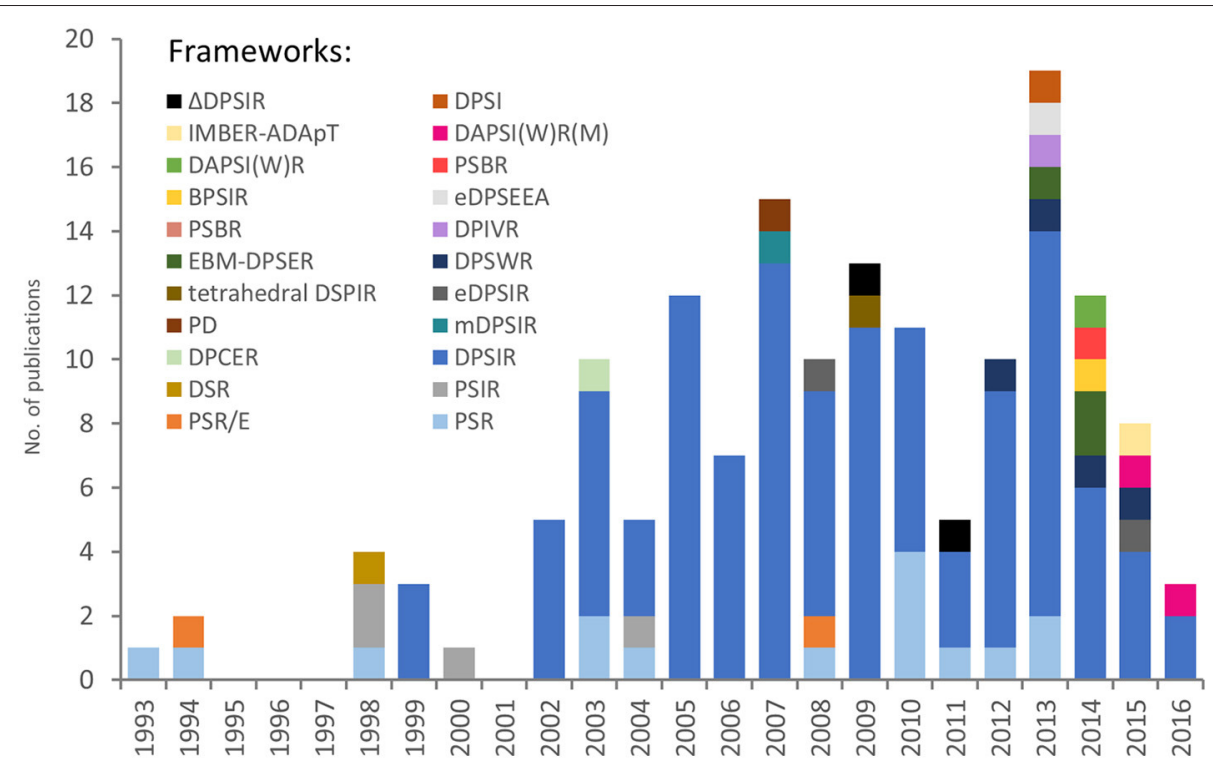

FIGURE 3 | Studies published per year (from those included in the review, $N=152$ ).

given that ecosystems are rarely affected in this single mode and, from the point of view of effects on State Change, a single activity may cause more than one pressure (or mechanism of pressure) or multiple activities might cause a similar single pressure. Further difficulties may exist with different levels of the same pressure from different activities or differing activity spatial or temporal (timescale) footprints in a defined area. At another level, an impact from several pressures or activities might require a single or integrated response or measure. However, this has been recognized and there have been a number of developments to try and deal with more real-world and complex systems. Atkins et al. (2011) used the first nested-DPSIR approach where their marine case study area had many activities that required multiple DPSIRs nested to provide a more holistic view of complex ecosystems. The individual activity DPSIRs could be grouped with their Response components linked within one common Response area, which would comprise an integrated management plan of the case study area. Scharin et al. (2016) have also used this approach in a Baltic Sea case study with the more-evolved DAPSI(W)R(M) framework, where different sectoral activity chains each produce a state change where their sum total is the current state of the ecosystem. They also re-grouped the activities chains around Response to propose an integrated management plan. DAPSI(W)R(M) also can be nested spatially and sequentially, for example across ecosystem boundaries from a river catchment area through an estuary into the sea. Dolbeth et al. (2016) also used the Atkins et al. (2011) approach with nested DPSIR cycles grouped around a central management response, but with possible interactions between the different independent activity cycles and also beyond single area ecosystems at a pan-European level for lagoonal ecosystems. Smith et al. (2016) have also taken the Atkins et al. (2011) concept forward by rotating common grouped DPSIR cycles around a common pressure (for example seabed abrasion caused by individual DPSIR cycled marine activities) and then building up a three dimensional picture of an area affected by many different pressure cycles. All these developments have shown the adaptability of a simple DPSIR concept to a more complete ecosystem approach.

The essence of any framework which is to be successfully and widely applied is that it should be adaptable and, as emphasized here, have an ability to deal with generic and sitespecific problems. It must encompass the inherent complexity and connectivity in all environments but especially marine, estuarine, and coastal systems. That adaptability resulting from complexity has been described by Gregory et al. (2013), using terms more common in social rather than natural sciences, as the need for the use of Problem Structuring Methods (PSMs) which enable us to learn from Complex Adaptive Systems (CAS) theory. In particular, both in general terms and specifically for marine environmental management this then encompasses and tackles what are regarded by social scientists as "wicked problems," a particular challenge in marine systems (Jentoft and Chuenpagdee, 2009; Gregory et al., 2013). While such "wicked problems" have been long-acknowledged in social sciences (Rittel and Webber, 1973), and regarded as problems that are "difficult or impossible to solve because of incomplete, contradictory, and changing requirements that are often difficult to recognize" (https://en.wikipedia.org/wiki/ Wicked_problem), they are only now being acknowledged in the natural sciences. Here, we emphasize that we do now have the approaches, framework and background to tackle those problems.

\section{Overall Approach}

The analysis here has emphasized that, based on a long and extensive use, the DPSIR framework, its large number of 
derivatives and its recent expanded derivative DAPSI $(\mathrm{W}) \mathrm{R}(\mathrm{M})$ has the potential as a holistic and valuable tool for analysing cause-effect-response links, determining management measures and communicating these aspects as long as it is used in its entirety. It is required to cover the complexity of coastal and marine systems, the competing and conflicting uses and users and their effects and management but in particular all steps from identifying the source of the problems, their causes and consequences and the means by which they are addressed. It has the potential as a visualization tool for complex interactions and so is valuable for the many stakeholders involved in managing the marine system.

The framework also has the flexibility to be applied across many systems and geographical, it can link marine systems and it can show the connectivity between adjacent systems. In particular, it shows the way in which environmental management is not only embracing complex systems analysis but is very well suited to it because of the many competing aspects. Similarly, to be effectively used it requires effectively merging natural and social science and cooperation between natural and social scientists and thus requires multi- and cross-disciplinary approaches. Hence, it has the ability to solve what may be the seemingly "wicked problem" of integrated marine assessment and management, but with the proviso that we need to keep moving from conceptual and generic models to those which are specific and quantified.

\section{REFERENCES}

Andrulewicz, E. (2005). "Developing the DPSIR framework of indicators for management of human impact on marine ecosystems, Baltic Sea example," in Assessment of the Fate and Effects of Toxic Agents on Water Resources, eds I. E. Gonenc, V. G. Koutitonsky, B. Rashleigh, R. B. Ambrose Jr., and J. P. Wolflin (Dordrecht: Springer), 225-243. doi: 10.1007/978-1-4020-5528-7_10

Atkins, J. P., Burdon, D., Elliott, M., and Gregory, A. J. (2011). Management of the marine environment: integrating ecosystem services and societal benefits with DPSIR framework in a systems approach. Mar. Pollut. Bull. 62, 215-226. doi: 10.1016/j.marpolbul.2010.12.012

Azevedo, A., Sousa, A. I., Lencart e Silva, J. D., Dias, J. M., and Lillebo, A. I. (2013). "Application of the generic DPSIR framework to seagrass communities of Ria de Aveiro: a better understanding of this coastal lagoon," in Proceedings $12^{\text {th }}$ International Coastal Symposium, eds D. C. Conley, G. Masselink, P. E. Russell, and T. J. O'Hare (Plymouth), 19-24.

Barnard, S., and Elliott, M. (2015). The 10-tenets of adaptive management and sustainability - applying an holistic framework for understanding and managing the socio-ecological system. Environ. Sci. Policy 51, 181-191. doi: 10.1016/j.envsci.2015.04.008

Bell, S. (2012). DPSIR = A problem structuring method? An exploration from the "Imagine" approach. Eur. J. Oper. Res. 222, 350-360. doi: 10.1016/j.ejor.2012.04.029

Bidone, E. D., and Lacerda, L. D. (2004). The use of DPSIR framework to evaluate sustainability in coastal areas. Case study: guanabara Bay basin, Rio de Janeiro, Brazil. Reg. Environ. Change 4, 5-16. doi: 10.1007/s10113-003-0059-2

Bowen, R. E., and Ryley, C. (2003). Socio-economic indicators and integrated coastal management. Ocean Coast. Manage. 46, 299-312. doi: 10.1016/S09645691(03)00008-5

Boyes, S. J., and Elliott, M. (2014). Marine Legislation - the ultimate 'horrendogram': international Law, European Directives \& National

\section{AUTHOR CONTRIBUTIONS}

JP carried out the literature review, analysis, and prepared the figures. CS and KP set up the study and contributed data. All authors contributed to the text. All of the individuals entitled to authorship have been listed, contributed substantively to the research, read, and approved the submission of this manuscript.

\section{ACKNOWLEDGMENTS}

This manuscript is a result of DEVOTES (DEVelopment Of innovative Tools for understanding marine biodiversity and assessing good Environmental Status) project, funded by the European Union under the 7th Framework Programme, "The Ocean of Tomorrow" Theme (grant agreement no. 308392), http://www.devotes-project.eu. A preliminary version of this work is given as Smith et al. (2014) found on-line at http://www.devotes-project.eu/wp-content/uploads/2014/06/ DEVOTES-D1-1-ConceptualModels.pdf. The authors would also like to thank two reviewers for helping to improve the manuscript.

\section{SUPPLEMENTARY MATERIAL}

The Supplementary Material for this article can be found online at: http://journal.frontiersin.org/article/10.3389/fmars. 2016.00177

Implementation. Mar. Pollut. Bull. 86, 39-47. doi: 10.1016/j.marpolbul. 2014.06.055

Bricker, S. B., Ferreira, J. G., and Simas, T. (2003). An integrated methodology for assessment of estuarine trophic status. Ecol. Model. 169, 39-60. doi: 10.1016/S0304-3800(03)00199-6

Briggs, D. (2003). Making a Difference: Indicators to Improve Children's Environmental Health. Geneva: World Health Organization.

Burdon, D., Boyes, S. J., Elliott, M., Smyth, K., Atkins, J. P., Barnes, R. A., et al. (2015). Integrating natural and social sciences to manage sustainably vectors of change in the marine environment: dogger bank transnational case study. Estuar. Coast. Shelf Sci. doi: 10.1016/j.ecss.2015.09.012. [Epub ahead of print].

Butler, J. R. A., Skewes, T., Mitchell, D., Pontio, M., and Hills, T. (2014). Stakeholder perceptions of ecosystem service declines in Milne Bay, Papua New Guinea: is human population a more critical driver than climate change? Mar. Policy 46, 1-13. doi: 10.1016/j.marpol.2013.12.011

Carr, E. R., Wingard, P. M., Yorty, S. C., Thompson, M. C., Jensen, M. K., and Roberson, J. (2007). Applying DPSIR to sustainable development. Int. J. Sust. Dev. World 14, 543-555. doi: 10.1080/13504500709 469753

Casazza, G., Silvestri, C., and Spada, E. (2002). The use of bio-indicators for quality assessment of the marine environment: examples from the Mediterranean Sea. J. Coast. Conserv. 8, 147-156. doi: 10.1652/14000350(2002)008[0147:TUOBFQ]2.0.CO;2

Cave, R. R., Ledoux, L., Turner, K., Jickells, T., Andrews, J. E., and Davies, H. (2003). The Humber catchment and its coastal area: from UK to European perspectives. Sci. Total Environ. 314-316, 31-52. doi: 10.1016/S00489697(03)00093-7

Cook, G. S., Fletcher, P. J., and Kelble, C. R. (2014). Towrds marine ecosystem based management in South Florida: investigating the connections among ecosystem pressures, states and services in a complex coastal system. Ecol. Indic. 44, 26-39. doi: 10.1016/j.ecolind.2013.10.026 
Cooper, P. (2013). Socio-ecological accounting: DPSWR, a modified DPSIR framework, and its application to marine ecosystems. Ecol. Econ. 94, 106-115. doi: 10.1016/j.ecolecon.2013.07.010

Cormier, R., Kannen, A., Elliott, M., Hall, P., and Davies, I. M., (eds.). (2013). Marine and Coastal Ecosystem-Based Risk Management Handbook. ICES Cooperative Research Report No. 317.

Cox, M., Scheltinga, D., Rissik, D., Moss, A., Counihan, R., and Rose, D. (2004). "Assessing condition and management priorities for coastal waters in Australia," in Proceedings of the Coastal Zone Asia Pacific Conference (Brisbane,QLD)

Cranford, P. J., Kamermans, P., Krause, G., Mazurié, J., Buck, B. H., Dolmer, P., et al. (2012). An ecosystem-based approach and management framework for the integrated evaluation of bivalve aquaculture impacts. Aquacult. Environ. Interact. 2, 193-213. doi: 10.3354/aei00040

Dolbeth, M., Stålnacke, P., Alves, F. L., Sousa, L. P., Gooch, G. D., Khokhlov, V., et al. (2016). An integrated pan-European perspective on coastal Lagoons management through a mosaic-DPSIR approach. Sci. Rep. 6:19400. doi: 10.1038/srep19400

Eastwood, P. D., Mills, C. M., Aldridge, J. N., Houghton, C. A., and Rogers, S. I. (2007). Human activities in UK offshore waters: as assessment of direct, physical pressure on the seabed. ICES J. Mar. Sci. 64, 453-463. doi: 10.1093/icesjms/fsm001

EC (1999). Towards Environmental Pressure Indicators for the EU, 1st Edn. Luxembourg: Office for Official Publications of the European Communities.

EEA (1999). Environmental Indicators: Typology and Overview. Technical report No.25, European Environment Agency, Copenhagen.

Elliott, M. (2002). The role of the DPSIR approach and conceptual models in marine environmental management: an example for offshore wind power. Mar. Pollut. Bull. 44, iii-vii. doi: 10.1016/s0025-326x(02)00146-7

Elliott, M. (2011). Marine science and management means tackling exogenic unmanaged pressures and endogenic managed pressures - a numbered guide. Mar. Pollut. Bull. 62, 651-655. doi: 10.1016/j.marpolbul.2010.11.033

Elliott, M., Cutts, N. D., and Trono, A. (2014). A typology of marine and estuarine hazards and risks as vectors of change: a review for vulnerable coasts and their management. Ocean Coast. Manage. 93, 88-99. doi: 10.1016/j.ocecoaman.2014.03.014

Elliott, M., Mander, L., Mazik, K., Simenstad, C., Valesini, F., Whitfield, A., et al. (2016). Ecoengineering with Ecohydrology: successes and failures in estuarine restoration Estuar. Coast. Shelf Sci. 176, 12-35. doi: 10.1016/j.ecss.2016.04.003

EPA (1994). A Conceptual Framework to Support the Development and Use of Environmental Information. Environmental Statistics and Information Division. Office of Policy, Planning and Evaluation. EPA 230-R-94-012, USEPA, Washington DC.

EPA (2008). Indicator Development for Estuaries. Office of Water. EPA842-B-07004, ESEPA, Washington DC.

Espinoza-Tenorio, A., Montaño-Moctezuma, G., and Espejel, I. (2010). Ecosystem-based analysis of a marine protected area where fisheries and protected species coexist. Environ. Manage. 48, 739-750. doi: 10.1007/s00267-010-9451-0

Fletcher, P. J., Kelble, C. R., Nuttle, W. K., and Kiker, G. A. (2014). Using the integrated ecosystem assessment framework to build consensus and transfer information to managers. Ecol. Indic. 44, 11-25. doi: 10.1016/j.ecolind.2014.03.024

Fock, H. O., Kloppmann, M., and Stelzenmuller, V. (2011). Linking marine fisheries to environmental objectives: a case study on seafloor integrity under European maritime policies. Environ. Sci. Policy 14, 289-300. doi: 10.1016/j.envsci.2010.11.005

Gari, S. R. (2010). The Use of DPSIR and SAF for the Management of Eutrophication in the Ria Formosa. MSc thesis, University of Algarve, Portugal.

Gari, S. R., Newton, A., and Icely, J. D. (2015). A review of the application and evolution of the DPSIR framework with an emphasis on coastal social-ecological systems. Ocean Coast. Manage. 103, 63-77. doi: 10.1016/j.ocecoaman.2014.11.013

Garmendia, M., Bricker, S., Revilla, M., Borja, A., Franco, J., Bald, J., et al. (2012). Eutrophication assessment in Basque estuaries: comparing a North American and a European method. Estuar. Coast. 35, 991-1006. doi: 10.1007/s12237-0129489-8
Gimpel, A., Stelzenmuller, V., Cormier, R., Floeter, J., and Temming, A. (2013). A spatially explicit risk approach to support marine spatial planning in the German EEZ. Mar. Environ. Res. 86, 56-69. doi: 10.1016/j.marenvres.2013.02.013

Giupponi, C. (2002). "From the DPSIR reporting framework to a system for a dynamic and integrated decision process," in MULINO Conference on European Policy and Tools for Sustainable Water Management (Venice).

Giupponi, C. (2007). Decision support system for implementing the European Framework Directive: the MULINO approach. Environ. Model. Softw. 22, 248-258. doi: 10.1016/j.envsoft.2005.07.024

Gregory, A. J., Atkins, J. P., Burdon, D., and Elliott, M. (2013). A problem structuring method for ecosystem-based management: the DPSIR modelling process. Eur. J. Oper. Res. 227, 558-569. doi: 10.1016/j.ejor.201 2.11 .020

Henriques, S., Pais, M. P., Costa, M. J., and Cabral, H. (2008). Development of a fish-based multimetric index to assess the ecological quality of marine habitats: the Marine Fish Community Index. Mar. Pollut. Bull. 56, 1913-1934. doi: 10.1016/j.marpolbul.2008.07.009

Hills, J. M., Schoen, G., and Nadcrinicinii, A. (2013). Climate Change Vulnerability and Impact Assessment Review for the Black Sea Region. CLIMBIZ - Black Sea Trade and Investment Programme. Athens: UNDP.

Hoff, A., Andersen, J. L., Buisman, F. C., Frost, H., Murillas, A., and Powell, J. P. (2008). Economic Efficiency of Fisheries Management Measures in an Innovative Evaluation Framework Prespective. CEVIS Report, Institute of Food and Resource Economics, 169.

Holman, I. P., Rousevell, M. D. A., Shackley, S., Harrison, P. A., Nicholls, R. J., Berry, P. M., et al. (2005). A regional, multi-sectorial and integrated assessment of the impacts of climate and socio-economic change in the UK. Clim. Chang. 71, 9-41. doi: 10.1007/s10584-005-5927-y

Hossain, M.D.S., Hei, L., Rip, F. I., and Dearing, J.A. (2015). Integrating ecosystem services and climate change responses in coastal wetlands development plans for Bangladesh. Mitig. Adapt. Strateg. Glob. Change 20, 241-261. doi: 10.1007/s11027-013-9489-4

Jentoft, S., and Chuenpagdee, R., (2009). Fisheries and coastal governance as a wicked problem. Mar. Policy 33, 553-560. doi: 10.1016/j.marpol.2008.12.002

Karageorgis, A. P., Skourtos, M. S., Kapsimalis, V., Kontogianni, A. D., Th. Skoulikidis, N., Pagou, K., et al. (2005). An integrated approach to watershed management within the DPSIR framework: Axios River catchment and Thermaikos Gulf. Reg. Environ. Change 5, 138-160. doi: 10.1007/s10113-0040078-7

Kelble, C. R., Loomis, D. K., Lovelace, S., Nuttle, W. K., Ortner, P. B., Fletcher, P., et al. (2013). The EBM-DPSER conceptual model: integrating ecosystem services into the DPSIR framework. PLOS ONE 8:e70766. doi: 10.1371/journal.pone.0070766

Knights, A. M., Piet, G. J., Jongbloed, R. H., Tamis, J. E., White, L., Akoglu, E., et al. (2015). An exposure-effect approach for evaluating ecosystem-wide risks from human activities. ICES J. Mar. Sci. 72, 1105-1115. doi: 10.1093/icesj $\mathrm{ms} / \mathrm{fsu} 245$

Knudsen, S., Zengin, M., and Koçak, M. H. (2010). Identifying drivers for fishing pressure. A multidisciplinary study of trawl and sea snail fisheries in Samsun, Black Sea coast of Turkey. Ocean Coast. Manage. 53, 252-269. doi: 10.1016/j.ocecoaman.2010.04.008

Lange, M., Burkhard, B., Garthe, S., Gee, K., Kannen, A., Lenhart, H., et al. (2010). Analyzing Coastal and Marine Changes: Offshore Wind Farming as a Case Study. Zukunft Kuste - Coastal Futures Synthesis Report. LOICZ Research \& Studies No. 36. GKSS Research Center, Geesthacht.

Langmead, O., McQuatters-Gollop, A., and Mee, L. D. (2007). European Lifestyles and Marine Ecosystems: Exploring Challenges for Managing Europe's Seas. Plymouth: University of Plymouth Marine Institute.

Langmead, O., McQuatters-Gollop, A., Mee, L. D., Friedrich, J., Gilbert, A. J., Gomoiu, M.-T., et al. (2009). Recovery or decline of the northwestern Black Sea: a societal choice revealed by socio-ecological modelling. Ecol. Model. 220, 2927-2939. doi: 10.1016/j.ecolmodel.2008.09.011

Lewison, R. L., Rudd, M. A., Al-Hayek, W., Baldwin, C., Beger, M., Lieske, S. N., et al. (2016). How the DPSIR framework can be used for structuring problems and facilitating empirical research in coastal systems. Environ. Sci. Policy 56, 110-119. doi: 10.1016/j.envsci.2015.11.001 
Licht-Eggert, K. (2007). "Scenarios as a tool for Integrated Coastal Management (ICZM) - how to handle the aspects of quality of life?" in Coastal Development: The Oder Estuary and Beyond, eds G. Schernewski, B. Glaeser, R. Scheibe, A. Sekscinska, and R. Thamm. Coastline Reports 8, EUCC - The Coastal Union, Leiden, 265-275.

Lin, T., Xue, X.-Z., and Lu, C.-Y. (2007). Analysis of coastal wetland changes using the "DPSIR" model: a case study in Xiamen, China. Coast. Manage. 35, 289-303. doi: 10.1080/08920750601169592

Lowe, C. D., Gilbert, A. J., and Mee, L. D. (2014). Human-environment interaction in the Baltic Sea. Mar. Policy 43, 46-54. doi: 10.1016/j.marpol.2013.03.006

Lundberg, C. (2005). Conceptualizing the Baltic Sea ecosystem: an interdisciplinary tool for environment decision making. Ambio 34, 433-439. doi: 10.1579/0044-7447-34.6.433

Mangi, S. C., Roberts, C. M., and Rodwell, L. D. (2007). Reef fisheries management in Kenya: preliminary approach using the driver-pressure-state-impactsresponse (DPSIR) scheme of indicators. Ocean Coast. Manage. 50, 463-480. doi: 10.1016/j.ocecoaman.2006.10.003

Marinov, D., Galbiati, L., Giordani, G., Viaroli, P., Norro, A., Bencivelli, S., et al. (2007). An integrated approach for the management of clam farming in coastal lagoons. Aquaculture 269, 306-320. doi: 10.1016/j.aquaculture.2007.04.071

Martins, J. H., Camanho, A. S., and Gaspar, M. B. (2012). A review of the application of driving forces - Pressure - State - Impact - Response framework to fisheries management. Ocean Coast. Manage. 69, 273-281. doi: 10.1016/j.ocecoaman.2012.07.029

Mateus, M., and Campuzano, F. J. (2008). "The DPSIR framework applied to the integrated management of coastal areas," in Perspectives on Integrated Coastal Management in South America, eds R. Neves, J. W. Baretta, and M. Mateus (Lisbon: IST Press), 29-42.

Mysiak, J., Giupponi, C., and Rosato, P. (2005). Towards the development of a decision support system for water resources. Environ. Model. Softw. 20, 203-2014. doi: 10.1016/j.envsoft.2003.12.019

Ness, B., Anderberg, S., and Olsson, L. (2010). Structuring problems in sustainability science: the multi-level DPSIR framework. Geoforum 41, 479-488. doi: 10.1016/j.geoforum.2009.12.005

Newton, A., Icely, J. D., Falcao, M., Nobre, A., Nunes, J. P., Ferreira, J. G., et al. (2003). Evaluation of eutrophication in the Ria Formosa coastal lagoon, Portugal. Cont. Shelf Res. 23, 1945-1961. doi: 10.1016/j.csr.2003.06.008

Niemeijer, D., and de Groot, R. S. (2008). Framing environmental indicators: moving from causal chains to causal networks. Environ. Dev. Sustain. 10, 89-106. doi: 10.1007/s10668-006-9040-9

Nobre, A. M., Bricker, S. B., Ferreira, J. G., Yan, X., de Wit, M., and Nunes, J. P. (2011). Integrated environmental modeling and assessment of coastal ecosystems. Coast. Manag. 39, 536-555. doi: 10.1080/08920753.2011. 600238

Nunneri, C., and Hofmann, J. (2005). A participatory approach for integrated river basin management in the Elbe catchment. Estuar. Coast. Shelf Sci. 62, 521-537. doi: 10.1016/j.ecss.2004.09.015

Nuttle, W. K., and Fletcher, P. J. (eds.). (2013). Integrated Conceptual Ecosystem Model Development for the Florida Keys/Dry Tortugas Coastal Marine Ecosystem. NOAA Technical Memorandum, OAR-AOML-103/NOS-NCCOS163. Miami, FL.

OECD (1993). OECD Core Set of Indicators for Environmental Performance Reviews. A Synthesis Report by the Group on the State of the Environment. OECD, Paris.

O’Higgins, T., Cooper, P., Roth, E., Newton, A., Farmer, A., Goulding, I. C., et al. (2014). Temporal constrains on ecosystem management: definitions and examples from Europe's regional seas. Ecol. Soc. 19:46. doi: 10.5751/ES-06507190446

Ojeda-Martínez, C., Casalduero, F. G., Bayle-Sempere, J. T., Cebrián, C. B., Valle, C., Sanchez-Lizaso, J. L., et al. (2009). A conceptual framework for the integral management of marine protected areas. Ocean Coast. Manage. 52, 89-101. doi: 10.1016/j.ocecoaman.2008.10.004

Ou, C.-H., and Liu, W.-H. (2010). Developing a sustainable indicator system based on the pressure-state-response framework for local fisheries: a case study of Gungliau, Taiwan. Ocean Coast. Manage. 53, 289-300. doi: 10.1016/j.ocecoaman.2010.03.001

Pastres, R., and Solidoro, C. (2012). Monitoring and modeling for investigating driver/pressure-state/impact relationships in coastal ecosystems: examples from the Lagoon of Venice. Estuar. Coast. Shelf Sci. 96, 22-30. doi: 10.1016/j.ecss.2011.06.019

Perry, R. I., and Masson, D. (2013). An integrated analysis of the marine socialecological system of the Strait of Georgia, Canada, over the past four decades, and development of a regime shift index. Progr. Oceanogr. 115, 14-27. doi: 10.1016/j.pocean.2013.05.021

Pettersson, A. (2015). Indicators of Biodiversity. The Case of the Port of Gothenburg. Master's thesis in Industrial Ecology. Department of Energy and Environment, Division of Environmental System Analysis, Chalmers University of Technology.

Pirrone, N., Trombino, G., Cinnirella, S., Algieri, A., Bendoricchio, G., and Palmeri, L. (2005). The Driver-Pressure-State-Impact-Response (DPSIR) approach for integrated catchment-coastal zone management: preliminary applications to the Po catchment-Adriatic Sea coastal zone. Reg. Environ. Change 5, 111-137. doi: 10.1007/s10113-004-0092-9

Rapport, D., and Friend, A. (1979). Towards a Comprehensive Framework for Environmental Statistics: A Stress-Response Approach. Statistics Canada Catalogue 11-510. Ottawa: Minister of Supply and Services Canada.

Rittel, H. W. J., and Webber, M. M. (1973). Dilemmas in a general theory of planning. Policy Sci. 4, 155-169. doi: 10.1007/BF01405730

Robinson, L. A., Rogers, S., and Frid, C. L. J. (2008). A Marine Assessment and monitorIng Framework for Application by UKMMAS and OSPAR - Assessment of Pressures and Impacts. Phase II: Application for regional assessments. Joint Nature Conservation Committee contract No. C-08-0007-0027.

Rogers, S. I., and Greenaway, B. (2005). A UK perspective on the development of marine ecosystem indicators. Mar. Pollut. Bull. 50, 9-19. doi: 10.1016/j.marpolbul.2004.10.028

Rovira, J. L., and Pardo, P. (2006). Nutrient pollution of waters: eutrophication trends in European marine and coastal environments. Contrib. Sci. 3, 181-186.

Rudd, M. A. (2004). An institutional framework for designing and monitoring ecosystem-based fisheries management policy experiments. Ecol. Econ. 48, 109-124. doi: 10.1016/j.ecolecon.2003.10.002

Scharin, H., Ericsdotter, S., Elliott, M., Turner, R. K., Niiranen, S., Blenckner, T., et al. (2016). Processes for the sustainable stewardship of marine environments. Ecol. Econ. 128, 55-67. doi: 10.1016/j.ecolecon.2016.04.010

Scheren, P. A. G. M., Kroeze, C., Janssen, F. J. J. G., Hordijk, L., and Ptasinski, K. J. (2004). Integrated water pollution assessment of the Ebrié Lagoon, Ivory Coast, West Africa. J. Mar. Syst. 44, 1-17. doi: 10.1016/j.jmarsys.2003.08.002

Schernewski, G. (2008). First steps towards an implementation of coastal management: from theory to regional practise. Rostock. Meeresbiolog. Beitr. 19, $131-148$.

Smith, C., Papadopoulou, K.-N., Barnard, S., Mazik, K., Elliott, M., Patrício, J., et al. (2016). Managing the marine environment, conceptual models and assessment considerations for the European Marine Strategy Framework Directive. Front. Mar. Sci. 3:144. doi: 10.3389/fmars.2016.00144

Smith, C., Papadopoulou, K.-N., Barnard, S., Mazik, K., Patricio, J., Elliott, M., et al. (2014). Conceptual Models for the Effects of Marine Pressures on Biodiversity. DEVOTES Deliverable 1.1. Devotes FP7 Project. 80. Available online at: www.devotes-project.eu/wp-content/uploads/2014/06/DEVOTESD1-1ConceptualModels.pdf

Sundblad, E.-L., Grimvall, A., Gipperth, L., and Morf, A. (2014). Structuring social data for the Marine Strategy Framework Directive. Mar. Policy 45, 1-8. doi: 10.1016/j.marpol.2013.11.004

Svarstad, H., Petersen, L. K., Rothman, D., Siepel, H., and Wätzold, F. (2008). Discursive biases of the environmental research framework DPSIR. Land Use Policy 25, 116-125. doi: 10.1016/j.landusepol.2007.03.005

Tett, P., Gowen, R. J., Painting, S. J., Elliott, M., Forster, R., Mills, D. K., et al. (2013). Framework for understanding marine ecosystem health. Mar. Ecol. Progr. Ser. 494, 1-27. doi: 10.3354/meps10539

Trombino, G., Pirrone, N., and Cinnirella, S. (2007). A business-as-usual scenario analysis for the Po Basin-North Adriatic continuum. Water Resour. Manag. 21, 2063-2074. doi: 10.1007/s11269-007-9198-4

Tscherning, K., Helming, K., Krippner, B., Sieber, S., and Gomez y Paloma, S. (2012). Does research applying the DPSIR framework support decision making? Land Use Policy 29, 102-110. doi: 10.1016/j.landusepol.2011.05.009

Turner, R. K., Adger, W. N., and Lorenzoni, I. (1998a). Towards Integrated Modelling and Analysis in Coastal Zones: Principles and Practices. LOICZ Reports \& Studies No. 11, LOICZ IPO, Texel. 
Turner, R. K., Hadley, D., Luisetti, T., Lam, V. W. Y., and Cheung, W. W. L. (2010). An Introduction to Socio-Economic Assessment within a Marine Strategy Framework. London: DEFRA.

Turner, R. K., Lorenzoni, I., Beaumont, N., Bateman, I. J., Langford, I. H., and McDonald, A. L. (1998b). Coastal management for sustainable development: analysing environmental and socio-economic changes on the UK coast. Geogr. J. 164, 269-281. doi: 10.2307/3060616

Turner, R. K., and Schaafsma, M. (eds.). (2015). Coastal Zones Ecosystem Services: From Science to Values and Decision Making. Springer Ecological Economic Series. Springer. doi: 10.1007/978-3-319-17214-9

UNEP (1994). World Environment Outlook: Brainstorming Session. ENEP/EAMR. 94-5. Environment Assessment Programe Nairobi.

UNEP/MAP. (2012). State of the Mediterranean Marine and Coastal Environment, Athens: UNEP/MAP Barcelona Convention.

Vacchi, M., Montefalcone, M., Parravicini, V., Rovere, A., Vassallo, P., Ferrari, M., et al. (2014). Spatial models to support the management of coastal marine ecosystems: a short review of best practices in Liguria, Italy. Mediterr. Mar. Sci. 15, 172-180. doi: 10.12681/mms.535

Viaroli, P., Marinov, D., Bodini, A., Giordani, G., Galbiati, L., Somma, F., et al. (2007). Analysis of clam farming scenarios in the Sacca di Goro lagoon. Transit. Water. Mongr. 1, 71-92. doi: 10.1285/i18252273vln1p71

von Schirnding, Y. E. (2002). Health-and-environment indicators in the context of sustainable development. Can. J. Public Health, 93(Suppl. 1), S9-S15.

Vugteveen, P., van Katwijk, M. M., Rouwette, E., and Hanssen, L. (2014). How to structure and prioritize information needs in support of monitoring design for integrated coastal management. J. Sea Res. 86, 23-33. doi: 10.1016/j.seares.2013.10.013

Walmsley, J. J. (2002). Framework for measuring sustainable development in catchment systems. Environ. Manage. 29, 195-206. doi: 10.1007/s00267-001$0020-4$
Wang, C., Qu, A., Wang, P., and Hou, J., (2013). Estuarine ecosystem health assessment based on the DPSIR framework: A case of the Yangtze Estuary, China. J. Coast. Res. 65, 1236-1241. doi: 10.2112/SI65-209.1

Wolanski, E., Elliott, M. (2015). Estuarine Ecohydrology: An Introduction. Amsterdam: Elsevier.

Yee, S. H., Carriger, J. F., Bradley, P., Fisher, W. S., and Dyson, B. (2015). Developing scientific information to support decisions for sustainable coral reef ecosystem services. Ecol. Econ. 115, 39-50. doi: 10.1016/j.ecolecon.201 4.02 .016

Zaldívar, J.-M., Viaroli, P., Newton, A., de Wit, R., Ibañez, C., Reizopoulou, S., et al. (2008). Eutrophication in transitional waters: an overview. Transit. Water. Mongr. 1, 1-78. doi: 10.1285/i18252273v2n1p1

Zhang, X., and Zue, X. (2013). Analysis of marine environmental problems in a rapidly urbanising coastal area using the DPSIR framework: a case study in Xiamen, China. J. Environ. Plan. Manage. 56, 720-742. doi: $10.1080 / 09640568.2012 .698985$

Conflict of Interest Statement: The authors declare that the research was conducted in the absence of any commercial or financial relationships that could be construed as a potential conflict of interest.

The handling Editor declared a collaboration with the authors and states that the process nevertheless met the standards of a fair and objective review.

Copyright (๑ 2016 Patrício, Elliott, Mazik, Papadopoulou and Smith. This is an open-access article distributed under the terms of the Creative Commons Attribution License (CC BY). The use, distribution or reproduction in other forums is permitted, provided the original author(s) or licensor are credited and that the original publication in this journal is cited, in accordance with accepted academic practice. No use, distribution or reproduction is permitted which does not comply with these terms. 